\title{
EKSTRAK BUAH PEPAYA (Carica papaya L.) MENINGKATKAN KADAR CATALASE DAN GLUTATHIONE HATI TIKUS YANG TERPAPARLEAD ACETATE
}

\author{
Ma'rufah ${ }^{1)}$ dan M. Adib'), \\ ${ }^{1,2}$ Akademi Analis Kesehatan Malang \\ ufah_02@yahoo.com
}

\begin{abstract}
Pollution is an entry or inclusion living things, subtances, energy, and or other components into environment and or change of environment compositions because of human activity or natural process with the result that decrease of quality to certain level that causes doesn't work environment. Pollution can be caused many subtances that is heavy metal, i.e. lead acetate $(\mathrm{Pb})$. Lead acetate affect physiological aberration, biochemical, and behavior. Heavy metal induction induce ROS production act as destructive oxidants. Body capability to oxidant neutralize serviced by superoxyde dismutase (SOD), glutathione peroxidase (GPx), catalase (CAT), glutathione (GSH), vitamin $\mathrm{C}$, vitamin $\mathrm{E}$, and other antioxidants in the cell. Antioxidants synthesized by plants, which is papaya (Carica papaya L.). Papaya (Carica papaya L.) effect on CAT and GSH levels was performed on male mice wistar strain. Mice induced by lead acetate $20 \mathrm{gr} / \mathrm{Kg}$ weight dose for 6 weeks, given papaya extract 100, 200, and 400 $\mathrm{mg} / \mathrm{Kg}$ weight dose for 6 weeks. Further glutathione and catalase levels are measured on mice liver. This study proves, papaya extract increase catalase levels $(p=0,000)$ and glutathione levels $(p=0,000)$ on mice liver induced lead acetate. Papaya extract $400 \mathrm{mg} / \mathrm{Kg} /$ day most effective dose to increase catalase and glutathione levels on mice liver induced lead acetate.
\end{abstract}

Keywords: lead acetate, Carica papaya L., catalase, glutathione, mice

\section{PENDAHULUAN}

Pencemaran merupakan peristiwa masuknya atau dimasukkannya makhluk hidup, zat, energi, dan atau komponen lain ke dalam lingkungan dan atau berubahnya tatanan lingkungan oleh kegiatan manusia atau proses alam sehingga kualitas menurun sampai ketingkat tertentu yang menyebabkan lingkungan menjadi kurang atau tidak dapat berfungsi lagi. Sedangkan definisi pencemaran menurut UU no. 32 tahun 2009, pencemaran lingkungan hidup adalah masuk atau dimasukkannya makhluk hidup, zat, energi, dan/atau komponen lain ke dalam lingkungan hidup oleh kegiatan menusia sehingga melampaui baku mutu lingkungan hidup yang telah ditetapkan.
Pencemaran dapat terjadi oleh banyak zat, diantaranya adalah logam berat yaitu lead acetate $(\mathrm{Pb})$. Lead acetate merupakan polutan beracun yang ada di lingkungan dan kawasan industri. Masalah kesehatan dapat timbul akibat pencemaran air minum oleh $\mathrm{Pb}$ dan logam berat yang lain. Lead acetate mempengaruhi kelainan fisiologis, biokimia, dan tingkah laku. Organorgan penting yang menjadi target toksisitas $\mathrm{Pb}$ antara lain: ginjal, hati, limpa, dan testis (Suradkar, et al., 2010). Hati merupakan organ penting dan aktif terlibat dalam banyak fungsi metabolisme dan sering menjadi organ target sejumlah zat yang bersifat racun (Anuradha dan Krishnamorrthy, 2011). Kerusakan hati dikaitkan dengan perubahan fungsi metaboliknya. 
Lead acetate berbahaya bagi tubuh manusia, dalam jumlah kecil dapat menyebabkan kerusakan sel yang diperantarai oleh reactive oxygen species (ROS) yang terlibat dalam patologi terkait toksisitasnya. ROS merupakan respon imun alami yang dihasilkan tubuh sebagai respon terhadap invasi antigen. ROS merupakan molekul reaktif tergolong radikal bebas yang akan berikatan dengan elektron yang tidak berpasangan seperti ion superoxide $\left(\mathrm{O}_{2}^{-}\right)$, nitrogen oxide $(\mathrm{NO})$, dan hydroxyl radikal $\left(\mathrm{OH}^{-}\right)$(Haleagraha, et al., 2011 dan Attia, et al., 2013). Dalam konsentrasi yang tinggi, ROS dapat menjadi mediator kerusakan struktur sel, asam nukleat, lemak dan protein. Hydroxyl radikal diketahui bereaksi dengan seluruh komponen molekul DNA, merusak basa purin, pirimidin dan kerangka deoxyribosa (Valko, et al., 2006).

Paparan radikal bebas dengan berbagai penyebab akan membuat suatu organisme mengembangkan berbagai mekanisme penolakan. Mekanisme penolakan terhadap radikal bebas menginduksi stres oksidatif yang melibatkan: 1) mekanisme preventatif, 2) mekanisme perbaikan, 3) pertahanan fisik, dan 4) pertahanan antioksidan. Pertahanan antioksidan enzimatik meliputi superoxidedismutase (SOD), glutathione peroxidase (GPx), catalase (CAT), sedangkan antioksidan non enzimatik diperantarai oleh asam askorbat (vitamin C), $\alpha$-tocopherol (vitamin E), glutathione (GSH), carotenoid, flavonoid, dan antioksidan yang lain.

Induksi oleh logam berat dapat menyebabkan produksi ROS yang merusak, tidak hanya pada DNA, tetapi pada komponen sel yang lain meliputi residu fosfolipid polyunsaturated fatty acid yang sangat sensitif terhadap oksidan (Valko, et al., 2006). Reactive oxygen species (ROS) dapat secara langsung mengoksidasi GSH, atau secara tidak langsung terjadi oleh reaksi yang dikatalisasi GSH peroksidase (Lushchak, 2011). Salah satu pengaruh paparan logam berat adalah pada proses metabolisme GSH yang merupakan molekul antioksidan dalam tubuh hewan dan manusia, berperan sebagai komponen penting dalam proses detoksifikasi dan ekskresi logam berat (Nishanthi, et al., 2012 danSharma, et al., 2011). Selain molekul antioksidan, adapula pertahanan antioksidan enzimatik yang diperankan oleh SOD, GPx, dan CAT.

Pertahanan antioksidan enzimatik salah satunya diperankan oleh CAT. Dalam tubuh manusia dan tikus, CAT ditemukan secara dominan dalam hati, ginjal, dan sel darah merah. Dalam hati dan ginjal CAT ditemukan dalam peroksisom, sedangkan dalam sel darah merah CAT ditemukan sebgian dalam sitoplasma dan sebagian lagi terikat pada membran sel (Walid, et al., 1991). Paparan $\mathrm{Pb}$ akan menurunkan aktivitas CAT sebagaimana dibuktikan dalam penelitian Anuradha dan Krishnamoorthy (2011) bahwa dengan induksi $\mathrm{Pb}$ selama 90 hari dapat menurunkan aktivitas CAT secara signifikan $(38,18 \pm 3,67 \mu \mathrm{mol})$ dibandingkan dengan kelompok normal $(58,69 \pm 5,64 \mu \mathrm{mol})$.

Kemampuan tubuh tidak cukup untuk menetralisir senyawa oksidan akibat paparan bahan beracun dari lingkungan yang bersifat radikal (Goodman, 1995). Maka dibutuhkan makanan yang banyak mengandung antioksidan untuk membantu tubuh menetralisir radikal bebas. Salah satu buah yang banyak mengandung senyawa antioksidan seperti karotenoid di antaranya adalah buah pepaya. Buah pepaya matang sangat unggul dalam hal betakaroten (276 mikrogram/100 g), betacryptoxanthin (761 mikrogram/100 g), serta lutein dan zeaxanthin (75 mikrogram/100 g). Betakaroten merupakan provitamin A sekaligus antioksidan yang sangat ampuh untuk menangkal serangan radikal bebas. Karoten dapat menetralkan oksigen singlet reaktif dan mencegah pembentukan radikal peroxyl akibat peroksidasi lipida. Bahkan karoten tengah dikaitkan dengan fungsinya untuk mengurangi resiko kanker dan menetralkan radikal bebas karsinogen. Betakaroten salah satunya, mampu menghambat proses peroksidasi lipid pada 
liposom yang diinduksi oleh radikal bebas atau oksigen singlet (Halliwell dan Gutteridge, 2007; Mohammed et al, 2011)

\section{METODE PENELITIAN}

\subsection{Ekstraksi Buah Pepaya (Carica papaya}

\section{L.)}

Buah pepaya (Carica papaya L.) yang dipotong kecil-kecil, dikeringkan, kemudian dihaluskan. Ekstraksi dilakukan dengan metode perkolasi dengan pelarut etanol $96 \%$ sebanyak $1 \mathrm{~L}$ selama 24 jam. Fraksi etanol dipisahkan dari serbuk buah pepaya dengan cara disaring. Selanjutnya dilakukan evaporasi etanol dengan menggunakan rotary evaporator selama 2 hari dan hasilkan berupa ekstrak etanolik buah pepaya.

\subsection{Pengujian Ekstrak Buah pepaya (Carica papaya L.) pada Hewan Coba}

Hewan coba (tikus) dikelompokkan menjadi 5 kelompok:

Kelompok 1: tikus dengan diet normal dan aquades selama 6 minggu.

Kelompok 2: diberikan lead acetate dosis $20 \mathrm{mg} / \mathrm{kg}$ BB selama 6 minggu.

Kelompok 3, 4, dan 5: diberikan lead acetate dosis $20 \mathrm{mg} / \mathrm{kg}$ BB dan diberikan ekstrak buah pepaya dosis berturut-turut 100; 200; dan 400 mg/kg BB/hari selama 6 minggu. Setelah 6 minggu dilakukan pengukuran kadar glutathione (GSH) dan catalase (CAT).

Lead acetate dan ekstrak buah pepaya diberikan per oral melalui sonde.

\subsection{Homogenisasi Jaringan Hati Tikus}

Jaringan hati tikus dari semua kelompok perlakuan ditimbang masing-masing 1 gr. Selanutnya jaringan dicuci dengan PBS +
PMSF dan ditambahkan $150 \mu \mathrm{l}$ PBS + PMSF kemudian dihaluskan dengan pistil. Jaringan yang sudah dihaluskan ditambahkan PBS + PMSF 1:1. Larutan homogenat disentrifuse $12.000 \mathrm{rpm} 4^{\circ} \mathrm{C} 10$ menit didapatkan endapan dan supernatan (digunakan untuk mengukur kadar catalase dan glutahathione).

\subsection{Pengukuran Kadar Catalase (CAT) Hati Tikus}

Sampel homogenat diencerkan 500x (1:500) dengan PBS + PMSF. Kemudian menyiapkan larutan $\mathrm{H}_{2} \mathrm{O}_{2} \quad 10 \quad \mathrm{mM}$ diencerkan dengan dapar fosfat 100x. Selanjutnya menyiapkan kuvet spektrofotometer UV dan menyiapkan blanko campuran $50 \mu \mathrm{l}$ PBS dan $950 \mu \mathrm{l}$ $\mathrm{H}_{2} \mathrm{O}_{2}$. Setelah semua sampel siap, kemudian diukur absorbansi sampel dengan panjang gelombang $240 \mathrm{~nm}$.

\section{HASIL PENELITIAN}

Hasil pengamatan kadar catalase (CAT) dan glutathione (GSH) pada hati tikus yang diinduksi lead acetate

Penelitian pengaruh ekstrak buah papaya (Carica papaya L.) terhadap kadar catalase (CAT) dan glutathione (GSH) pada hati tikus jantan yang diinduksi lead acetate bertujuan untuk mengetahui adanya antioksidan alami yang terkandung dalam buah papaya. Dengan adanya daya antioksidan diharapkan dapat mengurangi resiko kerusakan hati yang diakibatkan oleh paparan $\mathrm{Pb}$ yang menjadi salah satu unsur pencemaran lingkungan.

Data hasil pengukuran kadar CAT dan GSH pada hati tikus jantan yang diinduksi lead acetate dapat dilihat pada gambar grafik seperti berikut ini: 


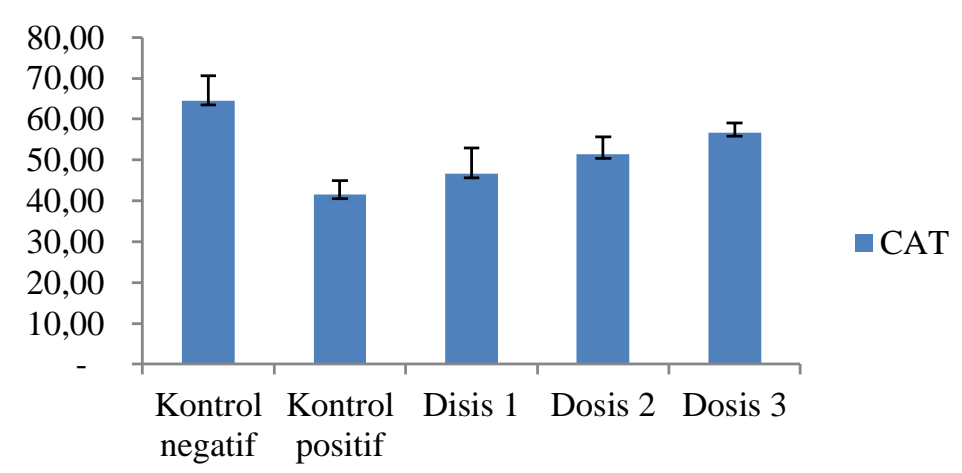

Gambar 1. Kadar catalase (U/mg protein) hati tikus yang diinduksi lead acetate dan diberikan ekstrak papaya dengan berbagai dosis

Pada gambar 1 dapat diketahui bahwa kontrol positif yang diinduksi lead acetate menunjukkan kadar catalase terendah dan kadar catalase kembali meningkat dengan pemberian ekstrak papaya. Peningkatan kadar catalase menunjukkan kadar mendekati kontrol normal pada pemberian ekstrak papaya dosis 400 $\mathrm{mg} / \mathrm{kg} \mathrm{BB} /$ hari.

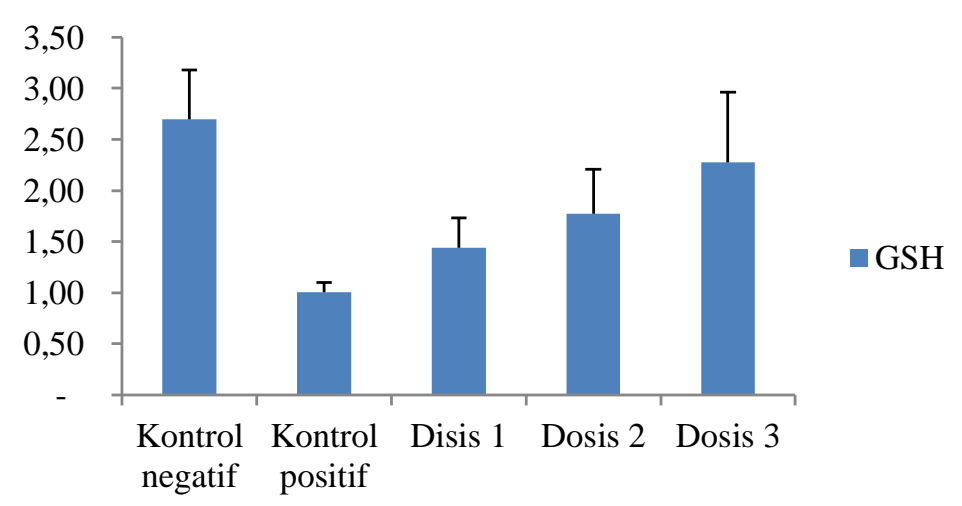

Gambar 2. Kadar glutathione ( $\mu \mathrm{mol} / \mathrm{gr}$ jaringan) hati tikus yang diinduksi dengan lead acetate dan diberikan ekstrak papaya dengan berbagai dosis.

Pada gambar 2 dapat diketahui bahwa kontrol positif yang diinduksi lead acetate menunjukkan kadar glutathione terendah dan kadar glutathione kembali meningkat dengan pemberian ekstrak pepaya. Peningkatan kadar glutathione mendekati kadar normal dengan pemberian ekstrak pepaya dosis $400 \mathrm{mg} / \mathrm{kg} \mathrm{BB} /$ hari.

Pemberian ekstrak buah pepaya secara signifikan dapat meningkatkan kadar catalase ( $p$ $=0.000)$ dan meningkatkan kadar glutathione $(\mathrm{p}$ $=0.000$ ) pada hati tikus yang diinduksi lead acetate. Ekstrak buah pepaya dosis $400 \mathrm{mg} / \mathrm{kg}$ $\mathrm{BB} /$ hari merupakan dosis yang paling efektif dalam meningkatkan kadar catalase dan kadar glutathione pada hati tikus yang diinduksi lead acetate sampai mendekati kadar normal.

\section{KESIMPULAN}

Pemberian ekstrak buah pepaya berbagai dosis dapat meningkatkan kadar CAT dan GSH pada hati tikus jantan yang dinduksi lead acetate. Dosis $400 \mathrm{mg} / \mathrm{kg} \mathrm{BB} /$ hari merupakan dosis efektif yang dapat meningkatkan kadar CAT dan GSH sampai mendekati kadar normal dengan peningkatan yang signifikan dibandingkan dengan kontrol positif (dengan perlakuan lead acetate $20 \mathrm{mg} / \mathrm{kg} \mathrm{BB} /$ hari). 


\section{DAFTAR PUSTAKA}

Anuradha, R. dan Krishnamoorthy, P. 2011. Antoxidant Activity of Methanolic Extract of Pongamia pinnata on Acetate Induced Hepatic Damage in Rats. African Journal of Biochemistry Research5 (12).

Attia, A. M. M. Ibrahim, F. A. A. Nabil, G. M. dan Aziz, S. W. 2013. Antioxidant Effect of Whole Ginger (Zingiber officinale Roscoe) Against Lead acetate Induced Hematotoxicity in Rats. Journal of Medicinal Plants Research 7 (17).

Goodman, S. 1995. Ester-C: Vitamin C Generasi III. Gramedia Pustaka Utama.

Haleagrahara, N. Chakravarthi, S. Kulur, A. B. dan Radhakrishnan, A. 2011. Effect of Chronic Lead acetate Exposure on Bone Marrow Lipid Peroxidation and Antioxidant Enzyme Activities in Rats. African journal of Pharmacy and Pharmacology 5 (7).

Halliwell B, Gutteridge JMC, 2007. Free Radicals in Biology and Medicine 4rd Edition. Oxford University Press. New York.

Lushchak, V. I. 2011. Glutathione Homeostasis and Functions: Potential Targets for Medical Interventions. Journal of Amino Acid. Doi: 10.1155/2012/736837.

Mohammed A, Abubakar SA, Smurugesh SM. 2011. Hepatoprotective effect of aqueous leaf extract of carica papaya linn. Against ccl4-induced hepatic damage in rats. International Journal of Pharmaceutical Sciences Review and Research Volume 11, Issue 2, November - December 2011; Article-003.

Nishanthi, J dan Anuradha, R. 2012. Efficacy of Tagetes erecta on Lead acetate Induced Oxidative Injury in Rat Kidney. International Journal of PharmTech Research. Vol 4.

Sharma, S. Sharma, V. Paliwal, R. dan Pracheta. 2011. Lead toxicity, Oxidative Damage and Health Implications. A Review. International Journal for Biotechnology and Molecular Biology Research 2 (13).

Suradkar, S. G. Vihol, P. D. Patel, J. H. Ghodasara, D. J. Joshi, B. P. dan Prajapati, K. S. 2010. Pathomorphological Changes in Tissues of Wistas Rats by Exposure of Lead acetate. Veterinary World Vol. 3 (2).

Valko, M., Leibfrits, D., Moncol, J., Cronin, M.T.D., Mazur, M., dan Telser, J. 2006. Free Radicals and Antioxidants in Normal Physiological Function and Human Disease. The International Journal of Biochemistry \& Cell Biology 39. 